\author{
ESTUDO DA ATIVIDADE ANTIMICROBIANA DE Tecoma stans (L.) ex Kunth \\ (BIGNONIACEAE)
}

\title{
STUDY OF THE ANTIMICROBIAL ACTIVITY OF Tecoma stans (L.) ex Kunth (BIGNONIACEAE)
}

\author{
GONÇALVES, Thaís Paula Rodrigues ${ }^{1}$; PARREIRA, Adriano Guimarães ${ }^{1}$; \\ LIMA, Luciana Alves Rodrigues dos Santos ${ }^{1 *}$ \\ ${ }^{1}$ Campus Centro-Oeste Dona Lindu, Universidade Federal de São João Del Rei \\ * Correspondence author \\ e-mail: luarsantos@ufsj.edu.br
}

Received 29 May 2020; received in revised form 15 June 2020; 03 July accepted 2020

\section{RESUMO}

A resistência antimicrobiana tornou-se uma grande preocupação em todo o mundo. No presente trabalho, foi realizada a triagem fitoquímica do extrato etanólico e das frações de flores de Tecoma stans e avaliou-se o potencial antimicrobiano, através do ensaio de microdiluição em caldo sobre 10 isolados de interesse clínico. Também foi avaliada a interação das combinações de amostras de $T$. stans com antimicrobianos comerciais. As amostras de $T$. stans demonstraram atividade antibacteriana e potencial fungistático sobre Proteus mirabilis, Proteus vulgaris, Staphylococcus aureus, Streptococcus mutans e Candida infanticola, especialmente o extrato etanólico e as frações diclorometânica e acetoetílica, com valores de Concentração Inibitória Mínima (CIM $2000-500 \mu \mathrm{g} / \mathrm{mL}$ ). A combinação das amostras de $T$. stans com os antimicrobianos mostrou efeitos sinérgicos e aditivos. Nas combinações classificadas como interação sinérgica, observou-se que a CIM para o antimicrobiano, em combinação com as amostras de $T$. stans, foi reduzida de 2 a 7 vezes em comparação com a CIM para o antimicrobiano, quando utilizado isoladamente. Os melhores resultados foram encontrados para a combinação do extrato etanólico com amoxicilina sobre $P$. mirabilis e do extrato etanólico e da fração diclorometânica com tetraciclina sobre S. aureus. Testes de combinações do extrato e das frações de $T$. stans com antimicrobianos são inéditos, tornando esses resultados promissores. $\mathrm{Na}$ caracterização fitoquímica foi possível observar a presença de alguns compostos fenólicos, o que pode justificar o potencial antimicrobiano de $T$. stans. Destaca-se a importância de identificar novos agentes antimicrobianos, alguns dos quais podem estar presentes na flora inexplorada do Brasil.

Palavras-chave: Antimicrobiano, Extrato, Fitoquímica, Sinergismo.

\begin{abstract}
Antimicrobial resistance has become a significant concern worldwide. In the present work was performed the phytochemical screening of ethanol extract and fractions of Tecoma stans flowers, and evaluated the antimicrobial potential by a broth microdilution assay against 10 isolates of clinical interest. Also was assessed the interaction of combinations of $T$. stans samples with commercial antimicrobials. The samples of $T$. stans demonstrated antibacterial activity and fungistatic potential against Proteus mirabilis, Proteus vulgaris, Staphylococcus aureus, Streptococcus mutans, and Candida infanticola, especially the ethanol extract and the dichloromethane and ethyl acetate fractions, with Minimal Inhibitory Concentration values (MIC 2000 - 500 $\mu \mathrm{g} / \mathrm{mL}$ ). The combination of $T$. stans samples with antimicrobials showed synergistic and additive effects. In combinations classified as synergistic interaction, was observed that MIC for the antimicrobial in combination with the samples of $T$. stans was reduced by 2 to 7 times compared to the MIC for the antimicrobial when used alone. The best results were found for the combination of the ethanol extract with amoxicillin against $P$.
\end{abstract}


mirabilis, and the ethanol extract and the dichloromethane fraction with tetracycline against S. aureus. Tests of combinations of extract and fractions of $T$. stans with antimicrobials are unprecedented, making these results promising. In the phytochemical characterization, it was possible to observe the presence of some phenolic compounds, which may justify the antimicrobial potential of $T$. stans. It is important to highlight the identification of new antimicrobial agents, some of which may be present in the unexplored flora of Brazil.

Keywords: Antimicrobial, Extract, Phytochemistry, Synergism.

\section{INTRODUCTION}

The increasing resistance of fungi and bacteria to traditionally used antimicrobials represents one of the major concerns faced by humanity in recent times, associated with severe consequences such as an increase in microbial infections (Costa and Junior, 2017; Nikaido, 2009). Therefore, the production of drugs from natural products has been encouraged in several countries (Aumeeruddy-Elalfi et al., 2015).

Higher plants may represent a promising alternative as they are capable of synthesizing compounds with antimicrobial activity, and these substances can be used against the development of infections in humans. In this sense, is highlight the phenolic compounds that are commonly associated with the antibacterial and antifungal activity of plants (Carvalho et al., 2018; Lima et al., 2016; Orhan et al., 2010). Also, plant extracts can be combined with commercial antibiotics and present some interactions. These combinations can expand the spectrum of activity of antimicrobials, increasing their effectiveness in the treatment of infections, and reducing the minimum inhibitory concentration against resistant pathogens (Berg and Lubert, 2008; Casanova and Costa, 2017).

Tecoma stans (L.) ex Kunth is an exotic species found in Brazil, which is commonly used in ornamentation. In other countries, such as Mexico, this species is also used in traditional medicine to treat fungal infections and digestive problems (Singh et al., 2013). However, only a few studies have reported its medicinal potential. Thus, this work evaluated the antimicrobial properties of $T$. stans flowers to confirm the medicinal potential of this species in Brazil.

\section{MATERIALS AND METHODS}

\subsection{Plant material and extraction}

The flowers of $T$. stans were collected in the Divinópolis municipality of $M G$ state

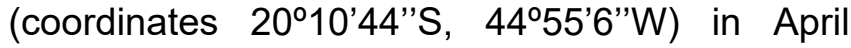

2018 , according to the registration of botanical material collection performed at the SISBIO (no. 30006 in 20/03/2018). A voucher specimen was deposited in the institution herbarium Pesquisa e Agropecuária de Minas Gerais (EPAMIG/PAMG) and identified as Tecoma stans (L.) Juss. ex Kunth (PAMG 58384).

The flowers were dried in an oven at 40 ${ }^{\circ} \mathrm{C}$ for 7 days, crushed in a mechanical mill, and extracted with ethanol $70 \%$ in a proportion of $9: 1$ (ethanol/plant) by turbo extraction (Ultra-Turrax, MA-102 Plus). The solvent was removed in a rotary evaporator (IKA-HB10) to obtain the ethanol extract (EE, $37.49 \mathrm{~g}$ ). Subsequently, $10 \mathrm{~g}$ of the obtained EE was solubilized in $100 \mathrm{~mL}$ of ethanol/water (7:3), and fractionated by a liquidliquid partition, obtaining hexane (HEX, $0.62 \mathrm{~g}$ ), dichloromethane (DCM, $1.19 \mathrm{~g}$ ), ethyl acetate $(\mathrm{AC}, 5.41 \mathrm{~g})$, and hydroethanol residue (HE, 2.08 g) fractions (Gonçalves, 2020).

\subsection{Phytochemical analysis}

The EE and fractions were submitted to phytochemical screening to evaluate the presence of the main classes of secondary metabolites for the identification of flavonoids, coumarins, saponin alkaloids, tannins, steroids, and triterpenoids (Matos, 2009; Silva et al., 2010), characterized by chemical reactions that result in the development of staining, precipitation, and foams.

A) Tannins: this test was performed by adding of $\mathrm{FeCl}_{3}$ alcoholic solution $5 \% \mathrm{w} / \mathrm{v}(5 \mathrm{~g} / 100 \mathrm{~mL})$ with the formation of precipitate or not, being blue precipitate indicative of hydrolyzable tannins, and green precipitate indicative of condensed tannins (Matos, 2009; Silva et al., 2010).

B) Triterpenoids and steroids: this test was performed by the Liebermann-Buchard reaction $\left(\mathrm{H}_{2} \mathrm{SO}_{4}+\right.$ acetic anhydride). The upper phase of blue or green color indicated the presence of steroids, and red, pink, purple, or violet interphasic halo indicated the presence of triterpenes (Matos, 2009; Silva et al., 2010). 
C) Saponins: the sample was shaken vigorously with distilled water for 1 minute, and the presence of persistent foam for 15 minutes indicated the presence of saponins (Matos, 2009; Silva et al., 2010).

D) Coumarins and anthraquinones: this test was performed by adding $\mathrm{NaOH}$ solution $1 \mathrm{M}$. The yellow color indicated the presence of coumarins, and violet to the purple color indicated the presence of anthraquinones (Silva et al., 2010).

E) Alkaloids: this test was performed by adding Drangendorff reagent with the formation of precipitate or not. The formation of insoluble and flocculent precipitate was indicative of the presence of alkaloids (Silva et al., 2010).

F) Flavonoids: this test was performed by adding of $\mathrm{H}_{2} \mathrm{SO}_{4}$ concentrated solution. The yellow, orange or red color was indicative of flavonoids (Silva et al., 2010).

\subsection{Antimicrobial potential assay}

The microorganisms used in this study originated from American Type Culture Collection (ATCC) and were provided by the microorganism reference laboratory of the Fundação Oswaldo Cruz (FIOCRUZ, Rio de Janeiro, Brasil). Eight species were used: Klebsiella oxytoca (ATCC 0182), Proteus mirabilis (ATCC 15290), Proteus vulgaris (ATCC 13315), Enterobacter cloaceae (ATCC 23355), Staphylococcus aureus (ATCC 25923), Staphylococcus epidermidis (ATCC 12228), Streptococcus mutans (NCTC 10449), Streptococcus agalactiae (ATCC 13813). In antifungal tests, Candida infanticola (UFSJ6A), and Candida glabrata (ATCC 2001) were used.

The bacterial susceptibility test was performed according to the CLSI (Clinical and Laboratory Standards Institute) document guidelines M100-S25 (2015) The bacterial inoculum colonies isolated from a 24-hour growth streak were transferred to tubes containing saline solution $0.85 \%(\mathrm{p} / \mathrm{v})$. Inoculum was prepared by dilution of a suspension corresponding to 0.5 on the McFarland density scale $\left(\mathrm{DO}_{530 \mathrm{~nm}}=0.19\right.$ 0.21) in Mueller-Hinton broth $(\mathrm{MH})(1: 10)$ to obtain a final inoculum with $7.5 \cdot 10^{5} \mathrm{UFC} / \mathrm{mL}$, which was used to assay. The fungal suspension was prepared in a similar way (NCCLS, 2002), to obtain a final inoculum with $1.10^{3} \mathrm{UFC} / \mathrm{mL}$, which was used to assay. Stretch marks of $48 \mathrm{~h}$ of growth were used to obtain the suspension in saline, and later adjusted to 0.5 on the McFarland scale $\left(\mathrm{DO}_{530 \mathrm{~nm}}=0.19-0.21\right)$, representing a cell density of approximately $1.10^{6} \mathrm{UFC} / \mathrm{mL}$. To obtain the final inoculum, two dilutions were performed, produced by transferring $20 \mu \mathrm{L}$ of the suspension to $980 \mu \mathrm{L}$ of Sabouraud dextrose (SD) broth and, subsequently, from $1 \mathrm{~mL}$ of the resulting suspension to $19 \mathrm{~mL}$ of SD broth. The samples were dissolved in water/DMSO (9:1), obtaining the initial concentration of $40 \mathrm{mg} / \mathrm{mL}$. The MIC was carried out in 96-well polystyrene microplates containing $100 \mu \mathrm{L}$ of the liquid medium, $20 \mu \mathrm{L}$ of the samples solution (ranging from 2000 to $2 \mu \mathrm{g} / \mathrm{mL}$, dissolved in 9:1 water:dimethylsulfoxide), and $100 \mu \mathrm{L}$ of the different microbial inoculum in each well. After microdilution, they were incubated in a bacteriological incubator (Nova Instruments) at $37{ }^{\circ} \mathrm{C}$ for $24 \mathrm{~h}$ for bacteria, and at $28{ }^{\circ} \mathrm{C}$ for $48 \mathrm{~h}$ for yeasts, and the minimum inhibitory concentration (MIC) was defined as the lowest concentration of samples without visible growth of microorganisms. Subsequently, the minimal bactericidal concentration (MBC) was defined as the lowest concentration of samples that inhibit bacterial growth, as described by Lyu et al. (2016). Amoxicillin, tetracycline, and ketoconazole were used as positive controls. Water/dimethylsulfoxide (DMSO) 9:1 v/v was used as solvent control. The tests were carried out in triplicate wells, with three independent repetitions between them.

\subsection{Evaluation of combinations}

For the evaluation of synergistic, additive, or antagonistic effects between antimicrobials (amoxicillin and tetracycline), and $T$. stans samples that presented a MIC (inhibition between 1000 and $500 \mu \mathrm{g} / \mathrm{mL}$ ) against the tested microorganisms, the "checkerboard" method was used (Lee et al., 2012; Oroojalian et al., 2010). In the 96-well plates, the antimicrobial was added horizontally, and then $T$. stans samples were added vertically in concentrations of 125 to 0.9 $\mu \mathrm{g} / \mathrm{mL}$, combined in a proportion of $1: 1$, to evaluate whether there is a combined antimicrobial effect. The resulting assay included a total of 64 combinations. After the distribution of the samples, $100 \mu \mathrm{L}$ of $\mathrm{MH}$ was added to each well with the bacterial inoculum at $7.5 \cdot 10^{5}$ $\mathrm{CFU} / \mathrm{mL}$, and the plates were incubated in an oven at $35^{\circ} \mathrm{C}$ for 16 to 20 hours. For the positive control, $\mathrm{MH}$ broth and microbial inoculum were used; only the $\mathrm{MH}$ broth was used for the sterility control, and water/dimethylsulfoxide (9:1) was used as the solvent control. As standards, amoxicillin and tetracycline antimicrobials were used. The MIC was determined for antimicrobials 
and $T$. stans samples alone and in different combinations. After visual reading from those wells that had no microbial growth detected with the naked eye, the calculation of the fractional inhibitory concentration (FIC) of each compound was determined by Equations 1 to 3 .

FIC (antimicrobial) $=$ MIC (antimicrobial) in combination / MIC (antimicrobial) alone

(Eq. 1)

FIC (extract) $=$ MIC (sample) in combination / MIC (sample) alone

$\mathrm{FIC}$ index $(\mathrm{FICl})=\mathrm{FIC}$ antimicrobial $+\mathrm{FIC}$ sample

The combinations were considered synergic when $\mathrm{FICl} \leq 0.5$, additive or indifferent at $0.5<\mathrm{FICl} \leq 2.0$, and antagonistic when $\mathrm{FICl}>$ 2.0 (He and Chen, 2006; Oroojalian et al., 2010; Palaniappan and Holley, 2010).

\section{RESULTS AND DISCUSSION}

The results of the phytochemical screening are presented in Table 1 . In the EE, flavonoids, alkaloids, coumarins, saponins, and condensed tannins were observed. The HEX fraction contained alkaloids and steroids. The $\mathrm{DCM}, \mathrm{AC}$, and $\mathrm{HE}$ fractions were similar and contained alkaloids, saponins, and coumarins. In the DCM fraction, flavonoids were also observed, and the $A C$ fraction also contained flavonoids, and condensed tannins. A previous study by Raju et al. (2011) confirmed the presence of flavonoids, saponins, tannins, and glycosides in the floral extracts of $T$. stans. Salvadó et al. (2002) showed the presence of triterpens, steroids, phenols, taninns, alkaloids, and flavonoids in dry and fresh leaves of $T$. stans.

The extract and fractions showed antimicrobial activity against $P$. mirabilis, $P$. vulgaris, S. aureus, S. mutans, and C. infanticola, except the HE fraction. The best results obtained in this study were for the EE, DCM, and $A C$ fractions (Table 2). The $E E$ and $A C$ fraction exhibited an effect against $P$. mirabilis, and the AC fraction against $S$. aureus (MIC of $500 \mu \mathrm{g} / \mathrm{mL}$ and $\mathrm{MBC}$ of $1000 \mu \mathrm{g} / \mathrm{mL}$ ). Some flavonoids have the ability to form antimicrobial barriers as a response by plants to microbial infection. Thus, there has been an increase in the number of studies on flavonoids as potential antimicrobial agents (Gutiérrez-Venegas et al., 2019). The presence of flavonoids in $T$. stans flowers may explain its antibacterial potential. GutiérrezVenegas et al. (2019) previously demonstrated antibacterial activity of the flavonoid apigenin against strains of Escherichia coli, Enterococcus faecalis, and $S$. aureus present in dental plaque.

The $T$. stans extract, and fractions that showed the most effective action in the MIC/MBC tests were submitted to the checkboard method to verify whether there were any interactions of these samples when combined with the commercial antimicrobials amoxicillin and tetracycline (Table 3 ). The samples showed synergistic and additive interactions when combined with commercial antimicrobials. In combinations classified as a synergistic interaction, we observed that the MIC for the antimicrobial in combination with $T$. stans samples was reduced by 2 to 7 times in comparison with the MIC of the antimicrobial when used alone. The best results were found for the combination of EE with amoxicillin against $P$. mirabilis, and EE and DCM fraction with tetracycline against $S$. aureus.

The association of plant extracts and antimicrobials has been observed previously. Araújo et al. (2014) reported the synergic potential of ethanol extracts from Lamiaceae species (Melissa officinalis, Mentha sp., Ocimum basilicum, Plectranthus barbatus, and Rosmarinus officinalis) with streptomycin against E. faecalis, S. aureus, S. mutans, E. coli, and Pseudomonas aeruginosa. The association of antimicrobials with medicinal plants or their derivatives in the treatment of microbial infections can increase the bioavailability of active substances, decrease toxicity and adverse effects, decrease resistance and increase therapeutic efficacy, allowing the use of these drugs when their effectiveness as a single agent in the treatment of infections is reduced (Chung et al., 2011; Van Vuuren and Viljoen, 2011).

\section{CONCLUSIONS}

In conclusion, these results regarding the antimicrobial effect of $T$. stans flowers corroborate the data already presented in the literature, and this study is the first to report these effects in plants of this species from Brazil. The samples obtained from the flowers of $T$. stans 
exhibited antimicrobial action against $P$. mirabilis, $P$. vulgaris, $S$. aureus, $S$. mutans, and $C$. infanticola, and that effect can be explained by the presence of phenolic compounds in these samples. The combination of plant samples with antimicrobials demonstrated an important interaction, potentiating the antimicrobial effects. The best results where observed for the combination of EE with amoxicillin against $P$. mirabilis, and EE and DCM fraction with tetracycline against $S$. aureus.

\section{ACKNOWLEDGMENTS}

We thank the Universidade Federal de São João Del-Rei (UFSJ), Conselho Nacional de Desenvolvimento Científico e Tecnológico (CNPq), Fundação de Amparo à Pesquisa do Estado de Minas Gerais (FAPEMIG), and Coordenação de Aperfeiçoamento de Pessoal de Nível Superior (CAPES) for all the support during the search. "This study was financed in part by the Coordenação de Aperfeiçoamento de Pessoal de Nível Superior - Brasil (CAPES) Finance Code 001."

\section{REFERENCES}

1. Costa, A. L. P., Junior, A. C. S. S. Resistência bacteriana aos antibióticos e saúde pública: uma breve revisão de literatura. Estação Científica (UNIFAP), 2017, 7, 45-57.

2. Nikaido, $\mathrm{H}$. Multidrug Resistance in Bacteria. Annu. Rev. Biochem., 2009, 78, 119-146.

3. Aumeeruddy-Elalfi, Z., Gurib-Fakim, A., Mahomoodally, F. Antimicrobial, antibiotic potentiating activity, and phytochemical profile of essential oils from exotic and endemic medicinal plants of Mauritius. Ind. Crop. Prod., 2015, 71, 197-204.

4. Carvalho, R. S., Carollo, C. A., De Magalhães, J. C., Palumbo, J. M. C., Boaretto, A. G., Nunes e Sá, I. C., Ferraz, A. C., Lima, W. G., de Siqueira, J. M., Ferreira, J. M. S. Antibacterial and antifungal activities of phenolic compound-enriched ethyl acetate fraction from Cochlospermum regium (Mart. Et. Schr.) Pilger roots: Mechanisms of action and synergism with tannin and gallic acid. S. Afr. J. Bot., 2018, 114, 181-187.

5. Lima, V. N., Oliveira-Tintino, C. D. M., Santos, E. S., Morais, L. P., Tintino, S. R.,
Freitas, T. S., Geraldo, Y. S., Pereira, R. L. S., Cruz, R. P., Menezes, I. R. A., Coutinho, H. D. M. Antimicrobial, and enhancement of the antibiotic activity by phenolic compounds: gallic acid, caffeic acid, and pyrogallol. Microb. Pathog., 2016, 99, 56-61.

6. Orhan, D. D., Özçelik, B., Özgen, S., Ergun, F. Antibacterial, antifungal, and antiviral activities of some flavonoids. Microbiol. Res., 2010, 165, 496-504.

7. Berg, J. M. T., Lubert, J. Bioquímica. $6^{a}$ ed. Guanabara Koogan, 2008, 545p.

8. Casanova, L. M., Costa, S. S. Synergistic interactions in natural products: Therapeutic potential and challenges. Revista Virtual de Química, 2017, 9, 575595.

9. Singh, A., Nagori, B., Mathur, K. Tecoma stans: An important medicinal plant. Int. J. Pharm., 2013, 3, 13-21.

10. Gonçalves, T. P. R. Estudo fitoquímico e avaliação do potencial antimicrobiano, sinérgico e antioxidante das flores de Tecoma stans (L.) Juss. ex Kunth (Bignoniaceae). Dissertação (Mestrado em Ciências Farmacêuticas). Universidade Federal de São João Del Rei, Divinópolis, 2020.

11. Silva, N. L. A., Miranda, F. A. A., Conceição, G. M. Triagem Fitoquímica de Plantas de Cerrado, da Área de Proteção Ambiental Municipal do Inhamum, Caxias, Maranhão. Scientia Plena, 2010, 6, 1-17.

12. Matos, F. J. A. Introdução à fitoquímica experimental. Edições UFC, 2009, 150p.

13. Clinical and Laboratory Standards Institute. Performance Standards for Antimicrobial Susceptibility Testing; Twenty-Fifth Informational Supplement. CLSI document M100-S25, 2015, 35, 3240.

14. NCCLS. Reference Method for Broth Dilution Antifungal Susceptibility Testing of Yeasts; Approved Standard-Second Edition. NCCLS document M27-A2. Pennsylvania, United States, 2002.

15. Lyu, Y., Yang, Y., Lyu, X., Dong, N., Shan, A. Antimicrobial activity, improved cell selectivity, and mode of action of short PMAP-36-derived peptides against bacteria and Candida. Sci Rep., 2016, 6, 1-12.

16. Lee, Y. S., Jang, K. A., Cha, J. D. Synergistic antibacterial effect between silibinin and antibiotics in oral bacteria. $J$. Biomed. Biotechnol., 2012,1-7. 
17. Oroojalian, F., Kasra-Kermanshahi, R., Azizi, M., Bassami, M.R. Phytochemical composition of the essential oils from three Apiaceae species and their antibacterial effects on food-borne pathogens. Food Chem., 2010, 120, 765770.

18. He, L., Chen, W. Synergetic activity of nisin with cell-free supernatant of Bacillus licheniformis ZJU12 against food-borne bacteria. Food Res. Int., 2006, 39, 995999.

19. Palaniappan, K., Holley, R. A. Use of natural antimicrobials to increase antibiotic susceptibility of drug-resistant bacteria. Int. J. Food Microbiol., 2010, 140, 164-168.

20. Raju, S., Kavimani, S., Uma, M. R. V., Sreeramulu, R. K. Tecoma stans (L.) Juss. Ex Kunth (Bignoniaceae): Ethnobotany, Phytochemistry, and Pharmacology. J. Pharm. Biomed. Sci., 2011, 8, 1-5.

21. Salvadó, A. C., Rivero, G. J., Naranjo, J. P. Droga cruda y extracto fluido de Tecoma stans L. Rev. Cuba. Plantas
Med., 2002, 7, 138-141.

22. Gutiérrez-Venegas, G., Gómez-Mora, J. A., Meraz-Rodríguez, M. A., FloresSánchez, M. A., Ortiz-Miranda, L. F. Effect of flavonoids on antimicrobial activity of microorganisms present in dental plaque. Heliyon, 2019, 5, 1-6.

23. Araújo, S. G., Alves, L. F., Pinto, M. E. A., Oliveira, G. T., Siqueira, E. P., Ribeiro, R. I. M. A., Ferreira, J. M. S., Lima, L. A. R. $S$. Volatile compounds of Lamiaceae exhibit a synergistic antibacterial activity with streptomycin. Braz. J. Microbiol., 2014, 45, 1341-1347.

24. Chung, P. Y., Navaratnam, P., Chung, L. $Y$. Synergistic antimicrobial activity between pentacyclic triterpenoids and antibiotics against Staphylococcus aureus strains. Ann. Clin. Microbiol. Antimicrob., 2011, 10, 25-31, 2011.

25. Van Vuuren, S., Viljoen, A. Plant-based antimicrobial studies - methods and approaches to study the interaction between natural products. Planta Med., 2011, 77, 1168-1182.

Table 1. Phytochemical analysis of flower extract and fractions of $T$. stans.

\begin{tabular}{cccccc}
\hline Secondary metabolites & EE & HEX & DCM & AC & HE \\
\hline Alkaloids & + & + & + & + & + \\
Anthraquinones & - & - & - & - & - \\
Coumarins & + & - & + & + & + \\
Steroids & - & + & - & - & - \\
Triterpenoids & - & - & - & - & - \\
Flavonoids & + & - & + & + & - \\
Saponins & + & - & + & + & + \\
Condensed Tannins & + & - & - & + & - \\
Hydrolyzable Tannins & - & - & - & - & -
\end{tabular}

EE: ethanol extract; HEX: hexane fraction; DCM: dichloromethane fraction; AC: ethyl acetate fraction; HE: hydroethanol fraction; (+): Presence; (-): Absence. 
Table 2. MIC values (MBC/MFC) in $\mu \mathrm{g} / \mathrm{mL}$ of microorganisms when treated with the extract and fractions.

\begin{tabular}{|c|c|c|c|c|c|c|c|}
\hline & $\mathrm{EE}$ & HEX & $\mathrm{DCM}$ & $A C$ & AMX & TETRA & KETZ \\
\hline Strains & $\begin{array}{c}\text { MIC } \\
\text { (MBC) }\end{array}$ & $\begin{array}{c}\text { MIC } \\
\text { (MBC) }\end{array}$ & $\begin{array}{c}\text { MIC } \\
\text { (MBC) }\end{array}$ & $\begin{array}{c}\text { MIC } \\
\text { (MBC) }\end{array}$ & $\begin{array}{c}\text { MIC } \\
\text { (MBC) }\end{array}$ & $\begin{array}{c}\text { MIC } \\
\text { (MBC) }\end{array}$ & $\begin{array}{c}\text { MIC } \\
\text { (MFC) }\end{array}$ \\
\hline P. mirabilis & $\begin{array}{c}500 \\
(1000)\end{array}$ & - & $\begin{array}{c}1000 \\
(2000)\end{array}$ & $\begin{array}{c}500 \\
(1000)\end{array}$ & $\begin{array}{c}7 \\
(15)\end{array}$ & $\begin{array}{c}60 \\
(125)\end{array}$ & - \\
\hline P. vulgaris & - & $\begin{array}{c}2000 \\
(-)\end{array}$ & $\begin{array}{c}2000 \\
(-)\end{array}$ & $\begin{array}{c}2000 \\
(-)\end{array}$ & $\begin{array}{c}125 \\
(250)\end{array}$ & $\begin{array}{c}7 \\
(15)\end{array}$ & - \\
\hline S. aureus & $\begin{array}{c}1000 \\
(2000)\end{array}$ & $\begin{array}{c}2000 \\
(-)\end{array}$ & $\begin{array}{c}500 \\
(1000)\end{array}$ & - & $\begin{array}{c}15 \\
(30)\end{array}$ & $\begin{array}{c}7 \\
(15)\end{array}$ & - \\
\hline S. mutans & $\begin{array}{c}2000 \\
(-)\end{array}$ & - & - & - & $\begin{array}{c}15 \\
(30)\end{array}$ & $\begin{array}{c}15 \\
(30)\end{array}$ & - \\
\hline C. infanticola & - & - & $\begin{array}{c}2000 \\
(-)\end{array}$ & $\begin{array}{c}2000 \\
(-)\end{array}$ & - & - & $\begin{array}{c}500 \\
(1000)\end{array}$ \\
\hline
\end{tabular}

EE: ethanol extract; HEX: hexane fraction; DCM: dichloromethane fraction; AC: ethyl acetate fraction; AMX: amoxicillin; TETRA: tetracycline; KETZ: ketoconazole; MIC: minimum inhibitory concentration; MBC and MFC: minimum bactericidal and fungicidal concentration; - value not determined.

Table 3. $\mathrm{FICl}$ values of different combinations of samples of $T$. stans and commercial antibacterials on some microorganisms.

\begin{tabular}{|c|c|c|c|c|c|}
\hline Samples & $\begin{array}{c}\text { MIC in } \\
\text { combination } \\
\mu \mathrm{g} / \mathrm{mL}\end{array}$ & $\begin{array}{c}\text { MIC alone } \\
\mu \mathrm{g} / \mathrm{mL}\end{array}$ & FIC & $\mathbf{F I C l}$ & Activity \\
\hline \multicolumn{6}{|c|}{ P. mirabilis } \\
\hline 1. EE & 2 & 500 & 0.0040 & 0.1325 & Synergistic \\
\hline 2. AMX & 0.9 & 7 & 0.1285 & & \\
\hline 1. $\mathrm{EE}$ & 3 & 500 & 0.0060 & 2.0893 & Additive or \\
\hline 2. TETRA & 125 & 60 & 2.0833 & & Indifferent \\
\hline 1. DCM & 0.9 & 1000 & 0.0009 & 0.2866 & Synergistic \\
\hline 2. AMX & 2 & 7 & 0.2857 & & \\
\hline 1. DCM & 3 & 1000 & 0.0030 & 2.0863 & Additive or \\
\hline 2. TETRA & 125 & 60 & 2.0833 & & Indifferent \\
\hline 1. $A C$ & 0.9 & 500 & 0.0018 & 0.4303 & Synergistic \\
\hline 2. AMX & 3 & 7 & 0.4285 & & \\
\hline 1. $A C$ & 125 & 500 & 0.2500 & 1.2500 & Additive or \\
\hline 2. TETRA & 60 & 60 & 1 & & Indifferent \\
\hline \multicolumn{6}{|c|}{ S. aureus } \\
\hline 1. EE & 7 & 1000 & 0.0070 & 0.4736 & Synergistic \\
\hline 2. AMX & 7 & 15 & 0.4666 & & \\
\hline 1. $\mathrm{EE}$ & 2 & 1000 & 0.0020 & 0.1305 & Synergistic \\
\hline 2. TETRA & 0.9 & 7 & 0.1285 & & \\
\hline 1. DCM & 0.9 & 500 & 0.0018 & 0.4684 & Synergistic \\
\hline 2. AMX & 7 & 15 & 0.4666 & & \\
\hline 1. DCM & 3 & 500 & 0.0060 & 0.1345 & Synergistic \\
\hline 2. TETRA & 0.9 & 7 & 0.1285 & & \\
\hline
\end{tabular}

EE: ethanol extract; DCM: dichloromethane fraction; AC: ethyl acetate fraction; AMX: amoxicillin; TETRA: tetracycline. 